\title{
Brand Love: Mediating Role in Purchase Intentions and Word-of- Mouth
}

\author{
Muhammad Yasin ${ }^{1}$, Amjad Shamim² \\ ${ }^{1}$ (Department of Business and Economics, Foundation University Islamabad, Pakistan) \\ ${ }^{2}$ (Lecturer, Department of Business and Economics, Foundation University Islamabad, Pakistan)
}

\begin{abstract}
The objective of this research is two fold. First is to determine the impact of brand experience, brand trust and affective commitment on purchase intentions. Second is to ascertain the mediating role of brand love in the relationships of purchase intentions and word-of-mouth. The data was obtained from 265 cell phone customers from Islamabad and Rawalpindi cities of the Islamic Republic of Pakistan. Simple random sampling technique was used for the collection of data and the data was analyzed in SPSS 15.0 where correlation and regression analyses were performed. Results indicate that brand experience, brand trust and affective commitment have significant positive impacts on purchase intentions. In this relationship, the intensity of the impact of affective commitment is quite high as compared to other variables. Other results revealed that purchase intentions significantly predict brand love and word-of-mouth, and brand love also significantly predicts word-of-mouth. And finally, brand love has partial mediation affect in the relationship of purchase intentions and word-of-mouth.
\end{abstract}

Keywords - affective commitment, brand experience, brand trust, brand love, cell phone

\section{INTRODUCTION}

Brand love - a vital marketing concept got a confined consideration by marketing scholars in the recent decade (Bergkvist and Bech-Larsen, 2010). In spite of the fact that this area has been very narrowly discussed, there are some researchers and practitioners who are inquisitive enough to enlighten its distinctive dimensions (Albert, Cerag and Wesford, 2009). Though, 'Love' with respect to interpersonal relations seen in the perspective of mental state and abstract (Albert, Merunka and Valette-Florence, 2008), brand identification and sense of community as causes of brand love, brand loyalty and word-of-mouth as outcome of brand love (Bergkvist and Bech-Larsen, 2010), and the excite feelings that arises after a certain brand usage (Albert, Cerag and Wesford, 2009) have already been put under lime light in the brand management discipline.

Several other studies have been undertaken to analyze the factors of brand relationship quality but the outcomes and findings do not match up exactly to be applied to brand love as it depicts only once facet of brand relationship quality (Kressman et. al., 2006; Smit, Bronner and Tolboom, 2007). By observing limited confined research on this topic and its importance in the recent marketing world, we came up with different questions need to be answered, like what are important factors that lead to the development of brand love? Does brand love play mediating role in any of the factors? Consequently, in this study, we came up with different factors that affect purchase intentions which further leads to the brand love and positive word-of-mouth. Hence we have conducted an explanatory study in Pakistan to find how brand experience, brand trust and affective commitment impacts purchase intentions? Does purchase intentions results positive word-of-mouth? And does brand love play a mediating role in the purchase intentions and word-of-mouth?

\subsection{Brand Love}

\section{LiTERATURE REVIEW}

Brand love is a quite a new construct in the customer behavior literature few peoples are still known about this construct (Thomson, MacInnis and Park 2005-hereinafter referred to as TMP). Customers may cultivate the feeling of love toward some brand but this concept needs further more development to understand it. Brands are important in the consumer's daily life. Recent research emphasized on different types of relationship of consumer with the branded products. Research also focuses on brand attachment, brand commitment, brand loyalty and brand trust(kapferer and Laurent 1992, Thomson et al 2005, Samuelsen and sandvik 1998, Chaudhri and Holbrook 2001, Jacoby and Chesnut 1978).

The abstract idea of brand love is vibrant and need to be explored on a large scale but still it is less researched. Some authors discovered that love is a psychological state (Aron and Aron 1996). There are many characteristics which are associated with the consumers brand love. The characteristics included brand attachment, passion for a brand, positive evaluation of the brand, declarations of love and positive emotions toward the brand. One author defines brand love as the degree of obsessive emotions toward the brand love (Caroll and Ahuvia 2005). Loyal customers develop relationship with brand and they maintain long term 
relationship. There are six types of relationship which are richer, deeper, more long lasting feeling then simple preference of customer (Fournier 1998). Brand love can also be defined as three-dimensional construct which is made of affiliation and dependence, predilection to help and absorption and exclusivity (Rubin 1970).

\subsection{Positive word-of -mouth}

The concept of Word-of-mouth is defined as an informal communications of the consumers with other consumers about the usage, performance, characteristics or ownership of the particular goods or services (Westbrook, 1987, p.261). Word-of-mouth is getting attention in the marketing literature and it is also becoming an important aspect (Anderson, 1998; Gilly et al. 1998; Money et al., 1998). Positive word-of-mouth has a great influence on any purchase decision, many research suggested that positive word-of -mouth has a great value for goods and services Ettenson and Turner, 1997; Heskett et al., 1997;Murray, 1991). It is also a recommendation which is often enough to persuade someone to try a certain product or service provider (Gremler, 1994; Price and Feick, 1984; Reingen, 1987). Now firms are encouraging positive word-of-mouth behavior because it can increase the number of customers. For getting more positive word-of-mouth firms are concentrating on different strategies like reward dispensing strategies, money back guarantee and coupons. The other way is to satisfy the customer which helps naturally to lead these behaviors.

The basic key of word-of-mouth is employee-customer relationship. Employee-customer relationship is basically personal trust in an employee's trustworthiness and integrity (Morgan and Hunt, 1994). Once the customer's trust increases, positive word-of-mouth communication about the product or service more likely to increase. Trust is a magnitude of three interpersonal relationship dimensions which are awareness between customers and employees, an interaction between employees and customers (Gremler and Gwinner, 2000), carefulness and concern displayed by employee (Dubinsky, 1994; Lewis, 1991; Surprenant and Solomon, 1987). Customer's trust in a certain employee is expected to form if the employee knows and understand its customers well, employees have care and concern for the customers. Customer trust helps to increase the positive word-ofmouth communication (Rafaeli, 1989; Zeithaml, 1981). Firm productivity and profitability is a result of positive word-of-mouth communication. Positive word-of-mouth is conversation of consumers about their excellent experiences with certain goods and services of their families, friends and colleagues for persuading others to purchase (Reichheld et al., 1990).

\subsection{Consumer Purchase Intentions}

Many companies take advantage of known faces like celebrities in their advertisement to have their proficiency and practical acquaintances with the products and services. This approach is very helpful to make consumers memorize the product or service. Famous advertising celebrities produce good impacts on the minds of customers and also help to build brand trust and purchase intention. Endorsement advertising also enhances the product recognition (Maclnnis, Rao \& Weiss (2002), Laffery \& Goldsmith (1999), Goldsmith, Lafferty \& Newell 2000). In recent years celebrity advertisement increase tremendously and many companies are adopting this strategy (Hsu \& McDonald, 2002). According to the research of an advertising magazine it is concluded that US is spending billion of US dollar for TV commercial advertising and about 10\% of US dollar are paid to wellknown stars (celebrities). This result indicates that more companies are interested in using famous celebrities to publicize and promote their product or service. Celebrity advertisement can transfer a great feeling toward the consumer about the product (Chi, Yeh \& Huang 2009). Celebrities have great impact on the consumers purchase intention (Ohanian, 1990, 1991; Laffery \& Goldsmith, 1999; Bower \& Landreth, 2001; Chi, et al., 2009).

Endorser's celebrity advertisement can be divided in to three categories which are expertise, attractiveness and credibility (Ohania, 1990). When advertising celebrities have great professional knowledge and experience their impact on purchase intention is more significant than credibility and attractiveness. The interface between the celebrity image and a product or service also has great effect on the celebrity credibility (Chi, et al, 2009). Celebrity attractiveness is best way to plead consumer credibility (Freiden 1984). Celebrity expert recommendation can increase trust on a product and also increase on purchase intention and also helps to promote the product value and brand recognition (Maddux \& Rogers 1980). A consumer's feelings and evaluation and external factors develop consumer purchase intention and which is vital feature to envisage consumer behavior (Fishbein \& Ajzen 1975). Purchase intention can determine the prospect of a consumer to buy the product or service (Dodds, et al 1991, Schiffman \& Kanuk 2000, Yang 2009). Purchase intention indicate that consumers will chase their experience, liking and external environment to gather information about the products or services, evaluate alternatives and make final Decision about the product or service ( Zeithaml 1988, Dodds et al 1991, Schiffman \& Kanuk 2000 Yang 2009).

Advertising celebrity's popularity, attractiveness and expertise can appeal consumer's attraction in a short time and improve consumer's purchase intention (Chi, et al 2009). Advertising celebrity cam increase exposure rate and also can change consumer predilection and also promote consumer's purchase intention (Anand, Holbrook and Stephens (1988) and Laroche, et al (1996). If a brand provide multi-purpose functions 
and meet consumers needs and want than it will produce psychological associations and a unique relation with the brand (Fournier 1994).Consumer purchase intention is a result of consumer's perception about the product and it is also important element to predict consumer purchase interaction it is also stated that apparent value and apparent quality will impact the purchase intention (Monroe and Krishnan 1985). The higher purchase intention also increases the perceived quality (Zeithaml 1988).

\subsection{Brand Experience}

The literature related to branding has great concentration on the importance of building valuable brands by making affiliation between the customer and brand (Asker, D. (1996), Keller, k. (2003). Research has also claimed that now peoples are not interested in simply buy the products and services instead they buy the magnificent and expressive experiences about what is being sold to them (Brembeck, H. and Ekstrom, K., 2004, Gobe, M., 2001) Ratneshwar, S. and Mick, D. (2005)). This is predominantly true for the intangibles like services (O’Shaughnessy, J. and O'Shaughnessy, N. J. (2003), Pine 11, B.J. and Gilmore,J.H (1999), Pullman, M, E and Gross, M. A. (2004) ).

Still, most of the marketers of the services are not following this new emotional ontology. The most recent research claimed that customers who are less than $25 \%$ believe that service organizations are providing excellent and extra-ordinary customers' experiences. For the customer, the emotional experience related to the service brand is evenly important as the service itself (Crane, F., Kerin, R. and Hartley, S. (2007)). As research indicate that service marketers can build strong brands by creating and controling the customer's emotional brand experience. Basically the emotional branding is expressed as appealing the consumers to the level of senses and emotions. Creating a deep, long-lasting, cherished emotional connection to the brand that transcends material satisfaction. This can create long lasting experience that delivers an emotional fulfillment so that consumers' ca easily develops unique trust with the brand (Gobe (2001). This concept of brand experience is infact far beyond the traditional approach of branding ( Keller (2003). Providing an ultimate and long lasting branding experience needs an incorporated organizational effort so this can help consumers to always feel and satisfied about their consumption experience. By creating and managing effective emotional branding experience the service marketers can increase their sales, consumer loyalty and also it helps in the promotion of the service brand (Gapper, J. (2004), Gobe (2001).

Recent research has stated that brand experience is appealing lot of attraction in marketing practice. Many of the marketing researchers stated that understanding how consumers experience brand is vital for developing complete marketing strategies for goods and services. Many of the research are giving very useful concepts about the brand experience (Chattopadhyay and Loborie 2005, Pine and Gilmore 1999, Schmitt 1999, Shaw and Ivens 2002, Smith and Wheeler 2002).

Product experience occurs when consumers interrelate with the products for instance when consumer look for the product and then observe and evaluate them ( Hoch 2002). Every brand experience varies from one another in terms of strength and intensity. Some of the brand experiences are stronger than other brand experiences. Some of the brand experiences occur impulsively but they are very short lived other brand experiences occur more intentionally and have long lasting impression in the mind of customer. Long lasting brand experiences remained in the memory of consumer and also effects on the consumers satisfaction and loyalty (Oliver 1997, Reiched 1996). When consumers consume the products or services then experiences occurs. The consumption experiences vary from consumer to consumer. Many consumers experience different types of feelings like fantasies and fun (Holbrook and Hirschman 1982). Branding offers the brand managers and strategic marketers a prospect to emphasize the link between the brand's figurative meaning and the consumption experience (Sherry, 1998). It is suggested that branding can be used as a 3D brand building commercial by brand management (Sherry 1998).

Designs can also create significant role in creating and managing consistency within the assortment of brand's meaning. Design management is a complex process creation and making the decision that increases the strategic and managerial decisions of an organization (Borja de Mozota 2003). Basically, its effectiveness is based on how it is synchronized with many other managerial functions (Vazquez and Bruce 2002). By managing design management alongwith new product development process and brand building, it becomes easier for organizations to develop services and products that engender positive interface with the customers. That's why; the consumer-centred product design is budding as one of the best practice in many of the industries (Lojacono and Zaccai 2004, Siedel and Pinto 2005, Veryzer and Borja de Mozota 2005).

Design is a clear source of discrimination and design has also become a great fact for branding because better design can attain customer's attention more easily than a normal design product ( Steinbock 2005). Design can also serve as the unified aspect for all the elements that build up a brand experience. If the design is good than consumers can easily understand that what is brand stand for and what are the brands feature. It is important to have a strong integration between the brand and brand management (Beverland 2005, Borja de Mozota 2003, Kreuzbauer and Malter 2005, Stompff 2003, Schmitt 1999, Svengren-Holm and Johansson, 
2005). The design of brand become as a mean for creating strong brand experience (Kent 2003). Many research stated that words have less value than the visual symbols in the marketplace (Borja de Mozota 2003). In recent years branding is becoming important as a symbolic sign that concentrate on the creation of consumer experiences (Salzer-Morling and Strannegard 2004). The product designs which are appealing and attractive they always lead to positive brand experience and it also help in facilitating consumers interaction (Kreuzbauer and Malter 2005). Satisfaction of consumers also depends on the feature or design of the product. The visual designs increase the value for custotmers and have positive effect in the minds of consumers and also help to increase the performance of organization (Schmitt and Simonson 1997, Berkowitz 1987, Kreuzbauer and Malter 2005).

\subsection{Affective Commitment}

Employees' emotional affiliation to their brand or organization is an important way to determine the employee's devotion and emotion toward the brand or organization. An employees' who are affectively strong belonging to their organization always helps to increase the assets of an organization and also they are ready to chase the organization's goals (Meyer \& Allen, 1991; Mowday, Porter \& Steers, 1982). According to this point of view researches have found that there is a connection between effective commitment and absenteeism, performance and revenue ( Matieu \& Zajac, 1990, Meyer \& Allen 1997, Mowday et al., 1982).

Organizational support theory ( Eisenberger, Huntington, Hutchison \& Sowa (1986), Shore \& Shore $1995)$ helps the marketers in observing employees emotional obligation to their organization. This approach state that rewards increase the efforts of employees and this is important because employee assumes general beliefs that how much organization value their efforts and contribution (Eisenberger et al, 1986).

Brand image is an important key of marketing activities. A brand image represents customers' observation of a brand as shown by the brand affiliation held in consumer mind (Herzog (1963), Keller (1993)). 6Research indicates that these affiliations could create by the direct experience or from information gathered on a market offering or due to the market image of the brand. Brand icon is the mental image or awareness of brand with its symbolic meanings that consumers correlate with the important attributes of a product or service ( Dobni and Zinkhan (1990), Pedgett and Allen (1997), Aperia and Back (2004).

\subsection{Brand Trust}

Brand plays an important role in the process of consumers' choice of the product. Brand is an important link between the producer and the consumer, and offers the number of features to the customers that meet customer's needs through the process of purchase. The brand is main thing which customer consider while purchasing the product or service. The most customers know about the brand helps in making the link between the brand and loyalty to brand. The role of the brand is less significant than other features like price, packaging, technical characteristics in the assessment of the product or service (Serge 2000). Research indicates that wellknown brand can increase the benefits of products or service and lead to the delivery of information linked to these benefits more than ordinary brands (keller 2003). There are many brands available in the market, some are unfamiliar brand but mostly customers choose famous and well- known brands. A well-known brand is not only attractive for customer to buy that service or product but it also helps to create the repetitive purchase and it also helps to reduce the behavior resulting from the price instability ( Cadogan and Foster, 2000). Brand also help in the development process of the product identity ( Kohli and Thankor 2000). Brand plays an important role in the development of a company because well known brand easily attract customers also well known brands have great influence on the behavior of customer and also motivates customers to repeat the purchase process. Brand is becoming important factor in the policy of products manufacturers. Brand also increases the assets value of an organization.

\section{THEORETICAL FRAMEWORK}

Based on the above literature, following theoretical framework has been formulated.

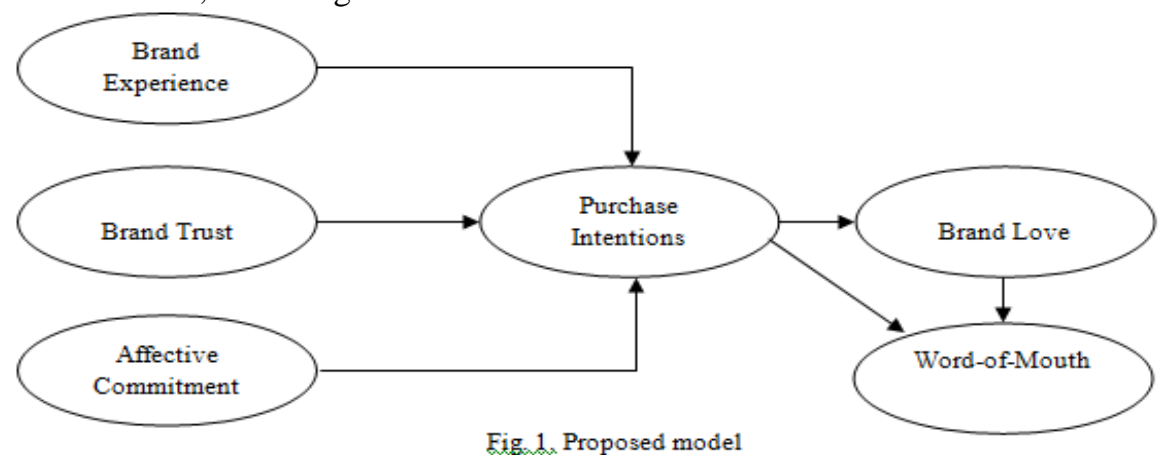

Fig. 1, Proposed model 


\section{METHODOLOGY}

The survey was conducted by using questionnaire. Target audiences were asked indicate the brand name which they use. Data was collected through simple random sampling technique. Sample size was calculated by keeping in mind the total estimated population of cell phone users in twin cities. An electronic web calculator "raosoft sample size calculator" was quite helpful in this matter. Total population of cell phone users in Pakistan 102.779 million indicated by Popular Engagement Policy Lab (PEPL). The scales of different authors were adapted and Cronbach's Alpha was tested to check the reliability of the instruments. For brand experience, we adapted the scale of Brakus, Schmitt, and Zarantonello, (2009) whose Cronbach's Alpha remains 0.79. For brand trust, the scale of Mohammad (2012) was adapted whose Cronbach's Alpha value remains at 0.77. Affective commitment was tested by using the scale of Iglesias, Singh, and Batista-Foguet, (2010) and Cronbach's Alpha value was 0.86. Similarly, Brand Love was tested by using the scale of Carroll and Ahuvia (2006) whose Cronbach's Alpha value was 0.88. The instrument of Wu, and Lo, (2009) was used for purchase intentions whose Cronbach's Alpha value was 0.80 . And finally, the Cronbach's Alpha value of word-of-mouth 0.78. The values are significant and indicate that all the instruments are reliable. Five-Point Likert scale was used as a measure. 5 were used as "strongly agree" and 1 as "strongly disagree". Total number of distributed questionnaires was 400 in total and 272 filled questionnaires were received back representing $68 \%$ response rate. 7 questionnaires were removed from the study due to incomplete data and finally 265 questionnaires were used in the study.

\subsection{Demographic Statistics}

\section{DATA ANALYSIS}

Participants were the mix of $62.3 \%$ male and $37.7 \%$ female. $41.5 \%$ participants were married and remaining $58.5 \%$ were unmarried. $16.2 \%$ participants were of $20<$ age, $46.8 \%$ were 20 to 30 years, $23.0 \%$ were of 31 to 40 years, $9.1 \%$ respondents were 41 to 50 years, $4.5 \%$ respondents were 51 to 60 years, and remaining $0.4 \%$ were $>60$ years of age.

In educational back ground, $0.0 \%$ were secondary school certificate holders, $20.8 \%$ were intermediate, $43.0 \%$ with bachelors degree holder, $30.6 \%$ were masters degree holder, $3.0 \%$ were having M.Phil, $1.1 \%$ were $\mathrm{PhD}$ degree holders, and remaining $1.5 \%$ were of others category including diploma holders. Overall the student vs. professionals' ratio remains at $40 \%$ and $60 \%$ respectively. Income level of respondents was also different according to their profession. About $38.5 \%$ were securing less than ten thousand Pakistani Rupees as most of them were students, $18.5 \%$ were earning 11000 to $20000,23.0 \%$ earning $2100030000,12.8 \%$ earning 31000 to $60000,3.8 \%$ earning 61000 to $80000,1.9 \%$ securing 81000 to 99000 , and remaining $1.5 \%$ are securing more than 100000 in Pakistani Rupees.

Table 1: Descriptive Statistics and Correlation Analysis

\begin{tabular}{|c|c|c|c|c|c|c|c|c|}
\hline Variables & Mean & $\begin{array}{l}\text { Std. } \\
\text { Dev. }\end{array}$ & BE & BT & AC & PI & BL & WOM \\
\hline Brand Experience (BE) & 3.534 & 0.746 & 1 & & & & & \\
\hline Brand Trust (BT) & 3.871 & 0.746 & $0.511^{* * *}$ & 1 & & & & \\
\hline Affective Commitment (AC) & 3.670 & 0.894 & $0.700^{* *}$ & $0.755^{* * *}$ & 1 & & & \\
\hline Purchase Intentions (PI) & 3.424 & 0.918 & $0.624^{* * *}$ & $0.713^{* *}$ & $0.795^{* *}$ & 1 & & \\
\hline Brand Love (BL) & 3.633 & 0.782 & $0.687^{* *}$ & $0.703^{* *}$ & $0.824^{* *}$ & $0.778^{* * *}$ & 1 & \\
\hline Word-of-Mouth (W-O-M) & 3.817 & 0.840 & $0.616^{* *}$ & $0.629^{* * *}$ & $0.752^{* *}$ & $0.725^{* *}$ & $0.795^{* *}$ & 1 \\
\hline
\end{tabular}

$* *$ Correlation is significant at the 0.05 level (2-tailed), $\mathrm{N}=265$.

Table 2 shows the descriptive statistics and correlation matrix. All correlations values are above 0.50 which indicates that the values are significant at $\mathrm{p}<0.05$ (2-tailed). Correlation values signify a positive relationship with considerable significance. Brand experience is having a strong positive correlation $(\mathrm{r}=0.511)$ with brand trust, affective commitment $(r=0.700)$, purchase intentions $(r=0.624)$, brand love $(r=0.687)$, and word-of-mouth $(\mathrm{r}=0.616)$.

Similarly, brand trust has significant correlations with the variables affective commitment $(\mathrm{r}=0.755)$, purchase intentions $(r=0.713)$, brand love $(r=0.703)$, and word-of-mouth $(r=0.629)$. Affective commitment has also positive correlations with purchase intentions $(r=0.795)$, brand love $(r=0.824)$, and word-of-mouth ( $r$ $=0.752)$. The correlations values of purchase intensions are also positive with brand love $(\mathrm{r}=0.778)$, and wordof-mouth $(\mathrm{r}=0.725)$, and finally the correlations value of brand love also indicates are positive relationship with word-of-mouth $(r=0.795)$. 
The mean values and standard deviation values for brand experience is $(\mathrm{M}=3.534$; $\mathrm{SD}=0.746)$, brand trust $(M=3.871 ; S D=0.746)$, affective commitment $(M=3.670 ; S D=0.894)$, purchase intentions $(M=3.424$; $\mathrm{SD}=0.918)$, brand love $(\mathrm{M}=3.633 ; \mathrm{SD}=0.782)$ and word-of-mouth $(\mathrm{M}=3.817 ; \mathrm{SD}=0.840)$.

Table 2: Impact of brand experience, brand trust and affective commitment on purchase intention

\begin{tabular}{|c|c|c|c|c|c|c|}
\hline & & $R^{2}$ & $\Delta R^{2}$ & $\beta$ & $t$ & $P$-value \\
\hline & & 0.672 & 0.668 & & & \\
\hline & & & & 0.141 & 2.828 & 0.005 \\
\hline Brand Experience & & & & 0.268 & 4.951 & 0.000 \\
\hline Brand Trust & Purchase Intention & & & 0.494 & 7.569 & 0.000 \\
\hline
\end{tabular}

a). Independent Variables: Brand Experience, Brand Trust, Affective Commitment

b). Dependent Variable: Purchase Intention

Regression analysis was performed in SPSS 15.0 to test the impacts. First the cause and effect relationship of brand experience, brand trust and affective commitment with purchase intentions was investigated for which following hypothesis was formulated:

H1: Brand Experience, brand trust and affective commitment positively impact purchase intentions

Results are presented in the table 3 indicates that $67 \%$ variation $\left(\mathrm{R}^{2}=0.672\right)$ in purchase intention is caused by the independent variables stated above. Beta value indicates that one unit increase in brand experience will increase purchase intention by $14 \%(\beta=0.141)$. It means that this variable has marginal positive impact on purchase intention and results are significant ( $\mathrm{p}$-value $=0.005<0.05$ ). Though brand experience predicted purchase intentions here but the impact is not so strong as compared to other two variables.

In the second stage, following was formulated:

H2: Brand trust has positive impact on purchase intentions

Results indicate unit increase in brand trust will increase purchase intentions by $26 \%(\beta=0.268)$. Here the results are significant at ( $\mathrm{p}$-value $=0.000<0.05$ ) level and hypothesis has been accepted. This relationship is observed stronger than the previous one. However, the final hypothesis in this model revealed a quite stronger impact:

H3: Affective commitment positively impact on purchase intentions

Results indicate that one unit increase in affective commitment will increase purchase intentions by 49 $\%(\beta=0.494)$. Here the results are significant at ( $\mathrm{p}$-value $=0.000<0.05)$ level and hypothesis has been accepted. Here it is worth mentioned that the affective commitment has quite stronger role in developing consumer purchase intentions.

In the below tables; we intended to check the mediating role of brand love in the relationships of purchase intentions and word-of-mouth. The results are interpreted as follows:

Table 3: Mediating role of brand love in the relationships of Purchase Intentions and word-of-mouth

\begin{tabular}{lccccl}
\hline & $\boldsymbol{R}^{2}$ & $\boldsymbol{\Delta R}^{\mathbf{2}}$ & $\boldsymbol{\beta}$ & $\boldsymbol{t}$ & $\boldsymbol{P}$-value \\
\hline Purchase Intentions $\rightarrow$ Brand Love & 0.606 & 0.604 & 0.778 & 20.098 & 0.000 \\
Brand Love $\rightarrow$ Word-of-Mouth & 0.633 & 0.631 & 0.795 & 21.286 & 0.000 \\
Purchase Intentions $\rightarrow$ Word-of-Mouth & 0.525 & 0.523 & 0.725 & 17.050 & 0.000 \\
Purchase Intentions $\rightarrow$ Brand Love & 0.661 & 0.658 & 0.268 & 4.672 & 0.000 \\
$\rightarrow$ Word-of-Mouth & & & & & \\
\hline
\end{tabular}

Initially the impact of purchase intentions on brand love has been tested by using the following hypothesis:

H4: Purchase intentions positively impact brand love

Results indicate that the rate of change in brand love due to purchase intentions is $60 \%\left(\mathrm{R}^{2}=0.606\right)$ which is quite high and indicates that the purchase intentions is a strong variable in developing brand love. Beta value revealed that one unit increase in purchase intensions will increase brand value by $77 \%(\beta=0.778)$ and the results are significant at $(\mathrm{p}$-value $=0.000<0.05)$. Hence a stronger significant impact of purchase intentions has been observed on brand love.

In the second relationship, the following hypothesis was formulated:

H5: Brand love has positive impact on word-of-mouth

The rate of change in word-of-mouth due to brand love has been observed as $63 \%\left(\mathrm{R}^{2}=0.633\right)$ which is quite high and acceptable. Unit change in brand love results $79 \%(\beta=0.795)$ change in word-of-mouth and the relationship is significant at ( $\mathrm{p}$-value $=0.000<0.05$ ). This hypothesis has strongly been accepted and indicates that brand love significantly creates positive word-of-mouth. 
The next hypothesis was to check the impact of purchase intentions on word-of-mouth as follows:

H6: Purchase intentions positively impact on word-of-mouth

It has been found that the rate of change in word-of-mouth due to purchase intentions was $52 \%\left(R^{2}=0.525\right)$ which is quite good indicating purchase intentions as an important factor in generating word-of-mouth. While regressing, the unit change in purchase intentions resulted $72 \%(\beta=0.725)$ change in word-of-mouth and ( $\mathrm{p}$-value $=0.000<0.05)$ indicates that the purchase intentions has strong positive impact on word-of-mouth.

In the final stage, we have tested the mediating role of brand love by using the following hypothesis:

H7: Brand Love plays a mediating role between purchase intentions and word-of-mouth

Regression analysis indicates a strongest rate of change in the relationships which is about $66 \%\left(\mathrm{R}^{2}=0.661\right)$. It can be seen from the above results of regression analysis that the coefficient for purchase intentions $\rightarrow$ word-of-mouth has been reduces from 0.795 to 0.268 when brand love is added to the regression which indicates that brand love playing a mediating effect in these relationships. As, the Baron and Kenny (1986), and Sobel (1982) mediation analysis has been proved, therefore, we declare that brand love has mediating effect in the formation of the relationships between purchase intentions and word-ofmouth.

\section{REFERENCES}

[1] Asker, D. (1996), "Building strong Brands", The Free Press New York

[2] Aperia, T. and Back, R. (2004), "Brand Relations Management, Bridging the Gap Between Brand Promise and Brand Delivery", Liber AB, Malmo.

[3] Aaker, D. A.(1991),"Managing brand equity capitalizing on the value of a brand name”, NewYork, Free Press

[4] Anand, P., Holbrook, M. B. and Stephens, D. (1988), "The formation of effective judgments: The cognitive affective model versus the independence hypothesis", Journal of Consumer Research, 15, pp.386-391.

[5] Aron, A, and Aron, EN. (1986), "Love as the expansion of self: understanding attraction and Satisfaction",New York: Hemisphere.

[6] Aron, A. and Westbay, L.(1996), "Dimensions of the prototype of love”,J Pers Soc Psychol,70, pp.535-51.

[7] Ahuvia, Aaron C., Bagozzi Richard, P. and Batra, Rajeev. (2007),"Brand love , the "what" and "so what"”, Marketing ScienceInstitute Conference, Mineapolis.

[8] Ahuvia, A. C. ( 2005 ), "Beyond the extended self:Loved objects and consumers' identity narratives” ,Journal of Consumer Research ,32 (1),pp.171- 184 .

[9] Anderson, E.W. (1998), “Customer satisfaction and word of mouth', Journal of Service Research, Vol. 1, August, pp.5-17.

[10] Allenby, and Lenk,(1995), "Reassessing Brand Loyalty, Price Sensitivity, and Merchandising Effects on Consumer Brand Choice",Journal of Business \& Economic Statistics 13(3):pp. 281-289

[11] Belk, R.W. (1988), "Possessions and the extended self', Journal of Consumer Research 15 (2): pp.139 - 168.

[12] Beverland, M. B. (2005), "Managing the design innovation-brand marketing interface: Resolving the tension between artistic creation and commercial imperatives", Journal of Product Innovation Management.

[13] Beverland, M. B. (2005), "Managing the design innovation-brand marketing interface: Resolving the tension between artistic creation and commercial imperatives", Journal of Product Innovation Management, Vol. 2.

[14] Borja de Mozota, B. (2003), "Design management: Using design to build brand value and corporate innovation", New York, NY: Allworth Press.

[15] Beverland, M. B. (2005), "Managing the design innovation-brand marketing interface: Resolving the tension between artistic creation and commercial imperatives", Journal of Product Innovation Management, Vol. 2.

[16] Borja de Mozota, B. (2003),“Design management: Using design to build brand value and corporate innovation”.

[17] Berkowitz, M. (1987), "Product shape as a design innovation strategy", Journal of Product Innovation Management, Vol. 4

[18] Bower, A. B. and Landreth, S. (2001), "Is beauty best? Highly versus normally attractive models in advertising", Journal of Advertising, 30(1), pp.1-12.

[19] Brakus, J.J., Schmitt, B. H. and Zarantonello, L., (2009), "Brand Experience: What Is It? How Is It Measured? Does It Affect Loyalty?", Journal of Marketing, Vol. 73, pp. 52-68.

[20] Carroll, B. A. and Ahuvia, A. C. (2006), "Some antecedents and outcomes of brand love", Marketing Letters, Vol. 17 Issue 2, pp. 79 -89 .

[21] Chattopadhyay, Amitava and Jean-Louis, Laborie. (2005), "Managing Brand Experience: The Market Contact Audit ${ }^{\mathrm{TM}}$ ", Journal Of Advertising Research.

[1] Cadogan, J. W. and Foster, B.D. (2000),"Relationship Selling and Customer Loyalty: An Empirical Investigation", Marketing Intelligence and Planning.

[2] Chi, H. K., Yeh, H.R. and Huang, M.W. (2009), “The Influences of advertising endorser, brand image, brand equity, price promotion on purchase intention: The mediating effect of advertising endorser", The Journal of Global Business Management, 5(1), pp.224233.

[3] Chi, H. K., Yeh, H. R., and Huang, M. W. (2009), "The Influences of advertising endorser, brand image, brand equity, price promotion on purchase intention: The mediating effect of advertising endorser", The Journal of Global Business Management, 5(1), pp.224-233.

[4] Chi, H. K., Yeh, H. R. and Yang, Y. T. (2009), "The impact of brand awareness on consumer purchase intention: The mediating effect of perceived quality and brand loyalty", Journal of International Management Studies, 4(1), pp.135-144.

[5] Carman,(1970), "Correlates of Brand Loyalty: Some Positive Results", Journal of Marketing Research7(1), pp.67-76.

[6] Caroll, B.A. and Ahuvia, A.C. (2005), "Some antecedents and outcomes of brand love", Marketing Letters, 17, pp.79-89.

[7] Chaudhuri, Arjun. and Holbrook Morris, B. (2001), "The chain of effects from brand trust and brand affect to brand performance", The role of brand loyalty," Journal of Marketing, 2, pp.91-93.

[8] Caroll, Barbara, A. and Ahuvia Aaron, C. (2006), "Some antecedents and outcomes of brand love," Marketing Letters, 17 (2), pp.7989.

[9] Carroll, B.A. and Ahuvia , A.C. (2006), “Some antecedents and outcomes of brand love” ,Marketing Letters, Vol. 17 Issue 2, pp. 79 -89 .

[10] Chaudhuri, A. and Holbrook, M. (2001), "The Chain Effects from Brand Trust andBrand Affect to Brand Performance: The Role of Brand Loyalty", Journal of Marketing, 65 (2): pp.81-94.

[11] Dobni, D. and Zinkhan, G.M. (1990), "In search of brand image a foundation analysis", Advances in Consumer Research, Vol.17.

$$
\text { www.iosrjournals.org }
$$


[12] Dodds, W. B., Monroe, K. B. and Grewal, D. (1991), "Effect of price, brand and store information on buyers' product evaluations", Journal of Marketing Research, 28(3), pp.307-319.

[13] Dowling, G. and Uncles, M. (1997),“Do Customer Loyalty Programs Really Work?”, Sloan Management Review, 38 (4):pp. 71 -83.

[14] Freiden, J. B. (1984), “Advertising spokesperson effects: an examination of endorser type and gender on two audiences", Journal of Advertising Research, 24, pp.33-41.

[15] Fournier, S. (1994), “Consumers and Their Brands: Developing Relationship Theory in Consumer Research”, Journal of Consumer Research, 24 ,pp.343-373.

[16] Fournier, S. (1998), "Consumers and their brands: developing relationship theory in consumer research", Journal of Consumer Research, 24:3, pp.43-73.

[17] Fournier, Susan. and Yao, Julie. (1997), "Reviving brand loyalty: a reconceptualization within the framework of consumer-brand relationships", International Journal Research in Marketing,14, 5, pp.451-472.

[18] Gapper, J. (2004), "The Challenge of turning a brand in to an object of love", Financial Times, March 23, p.23.

[19] Goldsmith, R. E., Laffery, B. A. and Newell, S. J. (2000), "The impact of corporate credibility and celebrity credibility on consumer reaction to advertisements and brands",Journal of Advertising, 29(3), pp.43-54.

[20] Gremler, D.D. (1994), "Word-of-mouth about service providers: an illustration of theory development in marketing”, in Park, C.W. and Smith, D. (Eds), AMA Winter Educators Conference Proceedings: Marketing Theory and Applications, American MarketingAssociation, Chicago, IL, pp. 62-70.

[21] Gremler, D.D. and Gwinner, K.P. (2000), “Customer-employee rapport in service 34E Aubinsky, A.J. (1994)”,"What marketers can learn from the tin man," Journal of Services Marketing, Vol. 8, No. 2, pp. 36-44.

[22] Gounaris Spiros, and Stathakopoulos Vlasis, (2004), "Antecedents And Consequences of Brand Loyalty: An Empirical Study", Journal of Brand Management, 11,4; pp. 283- 306.

[23] Herzog, H. (1963), "Behavioral science 5concepts for analyzing the consumer" in Bliss, (P.ED), Marketing and the behavioral science, Allyn and Bacon, Inc.

[24] Hsu, C. K. and McDonald, D. (2002), “An examination on multiple celebrity endorsers in Advertising”, The Journal of Product and Brand Management, 11(1), pp.19-29.

[25] Herr, P.M., Kardes, F.R. and Kim, J. (1991), "Effects of word-of-mouth and product-attribute information on persuasion: an accessibility-diagnosticity perspective', Journal of Consumer Research, Vol. 17, March, pp.454-62.

[26] Iglesias, O., Singh, J. J. and Batista-Foguet, J.M. (2010), "The role of brand experience and affective commitment in determining brand loyalty", Journal of Brand Management, Vol. 18, 8, 570-582.

[27] Jacoby, W. and. Chestnut, R. (1978),'Brand Loyalty: measurement and management",

[28] John Wiley and Sons, New York.

[29] Kapferer and Laurent (1992), Thomson, et al. (2005), Samuelsen and sandvik, (1998),

[30] Keller, k. (2003), "Strategic Brand Management", Prentice-Hall, New Jersey.

[31] Kreuzbauer, R. and Matler, A. J. (2005), "Embodied cognition and new product design:

[32] Changing product form to influence brand categorization", Journal of Product Innovation Management, Vol. 22.

[33] Kreuzbauer, R. and Matler, A. J. (2005), "Embodied cognition and new product design: Changing product form to influence brand categorization", Journal of Product Innovation Management, Vol. 22.

[34] Keller, K.L. (1993a), "conceptualizing measuring and managing customer-based brand”, Journal of Marketing, Vol.57.

[35] Keller, K. L (1993b), “Concetualizing measuring and managing customer based brand Equity”, Journal of Marketing, Vol.57.

[36] Keller, K. L. (2003b), "Strategic brand management: building, measuring, and managing Brand equity", Second Edition, Upper Saddle River, Prentice Hall, NY.

[37] Kohli, C. and Thakor, M. (1997),"Branding Consumer Goods: Insights from Theory and Practice", Journal of Consumer Marketing, Vol.14, pp.206-219.

[38] Kandampully, J. and Suhartanto, D. (2000), "Customer loyalty in the hotel industry: The Role of customer satisfaction and image", International Journal of Contemporary Hospitality Management, Vol.12, No.6, pp.346-351.

[39] Knox, S. (1996), “The Death of Brand Deference: Can Brand Management Stopthe Rot?, " Marketing Intelligence \& Planning, 14 (7):pp. 35-40.

[40] Lojacono, G. and Zaccai, G. (2004), "The evolution of the design-inspired enterprise", MIT Sloan Management Review, Vol. 4.

[41] Lafferty, B. A. and Goldsmith, R. E. (1999), "Corporate credibility's role in consumers attitudes and purchase intentions when a high versus a low credibility endorser is used in the Ad", Journal of Business Research, 44, pp.109-116.

[42] Lafferty, B. A. and Goldsmith, R. E. (1999), "Corporate credibility's role in consumers' attitudes and purchase intentions when a high versus a low credibility endorser is used in the Ad", Journal of Business Research, 44,pp.109-116.

[43] Liu, Y. (2007),"The long term impact of loyalty programs on consumer purchase behavior and loyalty", Journal of Marketing, Vol.71, No.4, pp.19-35.

[44] Lewis, B. R. (1991), “Customer care in service organizations”, Management Decision, Vol. 29, No. 1, pp. 31-34.

[45] Meyer, J. P. and Allen, N.J. (1991), "A three-component conceptualization of Organizational commitment", Human Resource Management Review, I, pp. 61-89.

[46] Mathieu, J. E. and Zajac, D. (1990), “A review and meta-analysis of the antecedents, correlates and consequences of organizational commitment”, Psychological bulletin 108, pp.171-194.

[47] MacInnis, D. J., Rao, A. G., and Weiss, A. M. (2002), “Assessing when increased media weight of real-world advertisements helps sales". Journalof Marketing Research, 39(4), pp.391-407.

[48] Maddox, J. E. and Rogers, R. W. (1980),"Effects of human models on perceived product quality”, Journal of Applied Psychology, 57, pp.172-178.

[49] Maddox, J. E. and Rogers, R. W. (1980), “Effects of human models on perceived product quality”, Journal of Applied Psychology, 57, pp.172-178.

[50] Meyer, J. P. and Allen, N. J. (1997), “Commitment in the workplace, Theory, research and application”, Thousand Oaks, CA, Sage.

[51] Monroe, K. B. and Krishnan, R. (1985), "The effect of price on subjective product evaluations, perceived quality: How consumers view stores and merchandise",

[52] Morgan, R. M. and Hunt, S. D. (1994), “The commitment-trust theory of relationship marketing”, Journal of Marketing, Vol. 58, July, pp. 20-38.

[53] Mohammad, A.A.S. (2012), "The Effect of Brand Trust and Perceived Value in Building Brand Loyalty", International Research Journal of Finance and Economics, Issue 85.

[54] Mowday, R. T. and Steers, R.M. (1982),“Organizational linkages, The psychology of commitment, absenteeism, and turnover”, San Diego, CA, Academic press. 
[55] Ohanian, R. (1990), “Construction and validation of a scale to measure celebrity endorser, perceived expertise, trustworthiness, and attractiveness. Journal of Advertising, 19(3), pp.39-52.

[56] Ohanian, R. (1991),"The impact of celebrity spokesperson's perceived image on consumers intention to purchase", Journal of Advertising Research, 31(1), pp.46-55.

[57] Pine, Joseph, B. and James, H. Gilmore, (1999), "The Experience Economy: Work Is Theatre and Every Business a Stage", CambridgMA: Harvard Business School Press.

[58] Padgett, D. and Alle, D. (1997), "Communicating experience a narrative approach to Creating service brand image", Journal of Advertising, Vol.26.

[59] Rubin, Z. (1970), "Measurement of romantic love", J Pers Soc Psychol ,16 (2),pp.265-73.

[60] Rafaeli, A. (1989), "When clerks meet customers: a test of variables related to emotional expressions on the job", Journal of Applied Psychology, Vol.74, No. 3, pp. 385-93.

[61] Reichheld, F. F. and Sasser, W. E. Jr. (1990), “Zero defections: quality comes to services”, Harvard Business Review, Vol.68, pp. 105-11.

[62] Richins, M.L. (1983), “ Negative word-of-mouth by dis-satisfied consumers: a pilot study”, Journal of Marketing, 47 (Winter),pp. 68-78.

[63] Reichheld, F. (1996), “The Loyalty Effect”, Boston: Harvard Business School Press.

[64] Schmitt, Bernd, H. (1999), "Experiential Marketing: How to Get Customers to Sense, Feel, Think, Act, Relate to Your Company and Brands". New York, The Free Press.

[65] Shaw, Colin and John, Ivens. (2002), "Building Great Customer Experiences", New York: Palgrave/Macmillan.

[66] Siedel, V. and Pinto, J. P. (2005), "Social science strategies for user-focused innovation and design management", Design Management Review.

[67] Steinbock, D. (2005),"Design and mobile innovation", Design Management Review.

[68] Stompff, G. (2003), "The forgotten bond: Brand identity and product design", Design Management Journal, Vol. 1.

[69] Schmitt, B. H. (1999), "Experiential marketing: How to get customers to sense, feel, act and relate to your company and brands", New York, NY: Free Press.

[70] Svengren-Holm, L. and Johansson, U. (2005), "Marketing and design: Rivals or Partners? ”, Design Management Review, Vol. 1.

[71] Steinbock, D. (2005),"Design and mobile innovation", Design Management Review, Vol. 16.

[72] Siedel, V. and Pinto, J. P. (2005), "Social science strategies for user-focused innovation and design management", Design Management Review, Vol. 16.

[73] Steinbock, D. (2005), "Design and mobile innovation", Design Management Review, Vol. 16.

[74] Salzer-Morling, M. and Strannegard, L. (2004), "Silence of the Brands", European Journal of Marketing, Vol. 38.

[75] Schmitt, B. H. and Simonson, A. (1997), "Marketing aesthetics: The strategic Management of brands identity and image", New York, NY: Free Press.

[76] Schiffman, L. G. and Kanuk, L. L. (2000), “Consumer Behavior (7th ed.)”.Wisconsin: Prentice Hall.

[77] Samuelsen, Bendik, and Sandvik, Kare. (1998), "Effects of customerstate of commitment to service provider", In Proceedings of the 27th EMAC Conference, vol. 1, p.345-350.

[78] Surprenant, C.F. and Solomon, M.R. (1987), "Predictability and personalization in the service encounter", Journal of Marketing, Vol. 51, April, pp.86-96.

[79] Singh, J. (1988), “Consumer Complaint Intentions and Behavior: Definitional and Taxonomical Issues”, Journal of Marketing, 52, January, pp.93-107.

[80] Tucker,(1964), “The Development of Brand Loyalty”, Journal of Marketing Research, Vol. 1, Issue 3, pp.32-35.

[81] Thomson, Matthew, MacInnis, Deborah J. and Whan Park, C. (2005), "The Ties That Bind: Measuring the Strength of Consumers' Emotional Attachment to Brands," Journal of Consumer Psychology, 15 (1), pp.77-91.

[82] Thomson, Matthew, Deborah, MacInnis. and Park C.W. (2005), "The Ties that Bind: Measuring the Strength of Consumers' Emotional Attachments to Brands," Journal of Consumer Psychology, 15(1), pp.77-91.

[83] Thiele Sharyn Rundle, and Mackay Marisa Maio, (2001), “Assessing the Performance of Brand Loyalty Measures", The Journal of Services Marketing, 15, 6/7, pp.529-545.

[84] Vazquez, D. and Bruce, M. (2002), "Exploring the retail design process within a UK food Retailer", International Review of Retail, Distribution and Consumer Research.

[85] Veryzer, R. W. and Borja de Mozota, B. (2005),"The impact of user-oriented design on new product development: An examination of fundamental relationships", Journal of Product Innovation Management.

[86] Vazquez, D. and Bruce, M. (2002), "Exploring the retail design process within a UK food Retailer", International Review of Retail, Distribution and Consumer Research, Vol. 12.

[87] Veryzer, R. W. and Borja de Mozota, B. (2005),"The impact of user-oriented design on new product development: An examination of fundamental relationships", Journal of Product Innovation Management, Vol. 22.

[88] Van Trijp, Hans, C.M., Hoyer, Wayne, D. and Jeffrey, J. Inman. (1996), "Why Switch? Product-Category-Level Explanations for True Variety-Seeking Behavior," Journal of Marketing Research, 33 (3), pp.281-292.

[89] Whang, Yun-O., Allen, Jeff. Sahoury, Niquelle. and Zhang, Haitao.(2004), "Falling in love with a product: The structure of aromantic consumer-product relationship", Advances in Consumer Research, 31, pp.320-327.

[90] Westbrook, R.A. (1987), "Product/consumption-based affective responses and post purchase processes", Journal ofMarketing Research, Vol. 24, August, pp.258-70.

[91] Whang, Y.O., Allen , J., Sahoury , and Zhang, H. (2004),"Falling in love with a product: The structure of a romantic consumerproduct relationship", In: B.E. Kahn and M.F. Luce (eds.), Advances in Consumer Research, pp. 320 - 327.

[92] Wu, S-I. and Lo, C-L., (2009), "The influence of core-brand attitude and consumer perception on purchase intention towards extended product”, Asia Pacific Journal of Marketing and Logistics, Vol. 21 No. 1, pp. 174-194.

[93] Wyer, R. and Srull, T. (1989), "Person memory and judgment", Psychological Review, Vol. 96, No.1, pp.58-83.

[94] Yang, Y. T. (2009), "A study of purchase intention behavior to consumers on innovation technology smart phone in technology acceptance model and theory of reason action", Unpublished master thesis, Nan Hua University, Taiwan.

[95] Zeithaml, V. A. (1988), "Consumer perceptions of price, quality and value: a means-end model and synthesis of evidence", Journal of Marketing, 52, pp.2-22.

[96] Zeithaml, V. A. (1981), "How consumer evaluation processes differ between goods and services", in Donnelly, J.H. and George, W.R. (Eds), Marketing of Services, American Marketing Association, Chicago, IL, pp.186-90. 